\title{
Effect of fermentation methods on amino acids, fiber fractions and anti-nutritional factors in different plant protein sources and essential amino acid index for Penaeus vannamei Boone, 1931
}

\author{
R. JANNATHULLA, J. SYAMA DAYAL, D. VASANTHAKUMAR, K. AMBASANKAR \\ AND M. MURALIDHAR \\ ICAR-Central Institute of Brackishwater Aquaculture, 75, Santhome High Road, Raja Annamalaipuram \\ Chennai - 600 028, Tamil Nadu, India \\ e-mail:syamdayal@rediffmail.com
}

\begin{abstract}
The incorporation of plant protein sources in shrimp feed is limited due to unbalanced amino acids and higher anti-nutrients. In the present study, soybean meal (SBM), groundnut oil cake (GNC), rapeseed meal (RSM), sunflower oil cake (SFC) and guar meal (GRM) were subjected to natural, bacterial, fungal and yeast fermentation methods. The essential amino acid contents were increased by $4-28 \%$ in SBM, $7-26 \%$ in GNC, 3-27\% in RSM, $8-18 \%$ in SFC and $4-14 \%$ in GRM. The increase was better for lysine with fungal fermentation $(2.31-4.01 \%)$. The improvement in other limiting amino acids viz., methionine and tryptophan also showed positive response to fermentation. The analytical results showed improved essential amino acid index (EAAI) in the fermented ingredients and the increase was better with RSM (0.82 to 0.92) using Aspergillus niger. Fiber fractions were reduced ( $\mathrm{p}<0.05)$ in fungal and yeast treated samples but not due to natural or bacterial fermentation. The reduction of cellulose and hemicellulose was not only influenced by the inoculum but also on the ingredient used. The reduction of anti-nutrients $(\mathrm{p}<0.05)$ such as trypsin inhibitor, phytic acid, saponin, tannin, glucosinolate and guar gum were found to be lower in natural fermentation than other methods. The results indicated that fungal fermentation is more suitable for improving the nutritional quality of plant protein sources and this data will pave way for higher fishmeal replacement in shrimp feed formulations.
\end{abstract}

Keywords: Anti-nutrients, Essential amino acid index, Microorganisms, Plant protein sources, Solid state fermentation

\section{Introduction}

Fishmeal is the most common and expensive protein source used in aquafeed formulations. Commercially, it is included at above $20 \%$ in shrimp feed formulation since being highly digestible, palatable and also having excellent amino acid profiles and other essential nutrients to fulfill the dietary requirement of cultured species. Commercial shrimp feed production is expected to increase from 0.9 million $t$ in 1995 to 9.2 million $t$ in 2020 (Tacon and Metian, 2008). The sustainability of aquaculture growth depends on the ability of the nutritionists to find alternatives to fishmeal as the demand exceeds to its supply by 2050 (Halweil, 2008). Plant protein sources, especially certain oil cakes might be considered as a viable alternative to an extent due to their sustainable availability and reasonable price. The use of high levels of plant protein sources resulted in reduction in digestibility and growth performance in shrimp (Dayal et al., 2011). The lower performance of the plant protein sources was attributed to the deficiencies in essential amino acids like tryptophan, lysine and sulphur containing amino acids, higher content of fiber fractions and anti-nutrients by affecting digestibility and palatability of feed (Akiyama, 1991).

Solid state fermentation is reported as a viable processing technique to reduce the undesired substances and to enrich the nutritional quality of the agricultural residues (Shi et al., 2015). However, the information on effect of inoculums used for fermentation on fiber fractions and the overall essential amino acid index (EAAI) of plant protein sources for shrimp is not available. Hence, in the present study, five most potential plant protein sources viz., soybean meal (SBM), groundnut oil cake (GNC), rapeseed meal (RSM), sunflower oil cake (SFC) and guar meal (GRM) were treated by four different ways of solid state fermentation (SSF) (natural, bacterial, fungal and yeast) to know the suitability of the inoculums. The effect of fermentation was evaluated based on the essential amino acid requirements of Pacific whitelegged shrimp, Penaeus vannamei Boone, 1931 by calculating EAAI along with the reduction (\%) of both fiber fractions and anti-nutrients. The present results provide the baseline 
data to maximise the utilisation of these ingredients in shrimp feed formulations with simultaneous reduction of pressure on fishmeal demand.

\section{Materials and methods}

Ingredients and fermentation methods

Commercial feed ingredients such as SBM, GNC, RSM, SFC and GRM were purchased. The coarse ingredients were ground to fine particles lesser than 500 $\mu \mathrm{m}$ and stored.

The microorganisms Lactobacillus acidophilus (ATCC 4356), Aspergillus niger (ATCC 6275) and Saccharomyces cerevisiae (ATCC 9763) obtained from Himedia Laboratories were maintained in appropriate media (MRS broth for bacteria and potato dextrose agar for fungus and yeast) for five days at $35-37^{\circ} \mathrm{C}$ in a shaking incubator. The spores were harvested in $0.1 \%$ Tween 80 and were approximately adjusted to $10^{7}$ spores $\mathrm{ml}^{-1}$, whereas the bacterial colony was diluted to $10^{6}-10^{7} \mathrm{ml}^{-1}$. The plant protein sources were sterilised with moisture of $60-65 \%$ and were subsequently inoculated with respective microbial suspension $(5 \%)$ and the flasks were incubated at $35-37^{\circ} \mathrm{C}$ in a shaking incubator for three days. The fungal and yeast fermentation was carried out in $500 \mathrm{ml}$ Erlenmeyer flask covered with cotton plugs to facilitate air transfer whereas the bacterial fermentation was carried out in anaerobic condition by vacuum sealing. Simultaneously, another set of ingredients were allowed to ferment naturally without any inoculum at an ambient temperature. All the treatments were carried out in six replications and the final fermented products were collected after oven drying $\left(40-50^{\circ} \mathrm{C}\right)$.

\section{Laboratory analysis}

The amino acids were analysed using pre-column HPLC gradient system (Shimadzu Corp, LC-30AD) after hydrolysing the samples with $6 \mathrm{~N}$ hydrochloric acid in a sealed tube for $22 \mathrm{~h}$ at $110^{\circ} \mathrm{C}$ in a vacuum oven (Finlayson, 1964). The acid was drained using vacuum rotary evaporator (IKA, Model No: RE 10 C S84) and the residue was brought into diluent $(0.1 \mathrm{~N}$ hydrochloric acid) and then filtered using $0.2 \mu \mathrm{m}$ membrane syringe filter. YMC-Triart C18, RRH $(1.8 \mu \mathrm{m}, 2.1 \times 100 \mathrm{~mm}$ dimension) column was used to separate the amino acids after derivatisation with mercaptopropionic acid, O-pthaladehyde and fluorenylmethoxycarbonyl chloride under gradient elution using phosphate buffer $(20 \mathrm{~mm}$; buffer A) and combination of acetonitrile:methanol: water (45:40:15; buffer B) at a flow rate of $0.3 \mathrm{ml} \mathrm{min}^{-1}$. The gradient was changed by increasing buffer B concentration at the rate of $11-13 \%$ at $3 \mathrm{~min}, 31 \%$ at $5 \mathrm{~min}, 37 \%$ at $15 \mathrm{~min}, 70 \%$ at $20 \mathrm{~min}, 100 \%$ at $25-28 \mathrm{~min}$ and finally, $11 \%$ at $30 \mathrm{~min}$. Amino acids were identified and quantified by fluorescent detector (RF-20AXS) using amino acid mixer as an external standard (Sigma Aldrich, Cat. No: AAS18-5ml). Tryptophan being labile to acid hydrolysis, it was measured after alkali hydrolysis by spectrophotometric method (Sastry and Tammuru, $1985)$ at $500 \mathrm{~nm}$. The essential amino acid index (EAAI) was calculated based on the amino acid requirements of P. vannamei (Akiyama et al., 1991).

Fiber fractions namely neutral detergent fiber (NDF), acid detergent fiber (ADF), cellulose, hemicellulose and lignin content of selected plant protein sources were estimated as per the method of Van Soest (1963). Anti-nutritional factors such as trypsin inhibitor (Kakade et al., 1974), saponin (AOAC, 1997), phytic acid (Davis and Reid, 1979), tannin (Vannilin $\mathrm{HCl}$ ), glucosinolate (McGhee et al., 1965) and guar gum (Das et al., 1977) were analysed by standard methods.

\section{Statistical analysis}

The data was statistically evaluated by one way ANOVA using SPSS version 17.0. The post-hoc analysis was done using least significance difference. Comparison of means was carried out at $5 \%$ significance level $(\mathrm{p}<0.05)$.

\section{Results and discussion}

The nutritional quality of agricultural residues was improved by solid state fermentation through the reduction of undesired substances effectively compared to other detoxification process (Shi et al., 2015). The effect of different inoculums on essential amino acids and microbial degradation of anti-nutrients by natural, bacterial, fungal and yeast fermentation of various plant protein sources are discussed here.

Effect of SSF on essential amino acids (EAA) and essential amino acid index (EAAI)

Generally, shrimp feeds are formulated in terms of crude protein (CP) and the quality of protein sources is expressed as the amount of essential amino acids in the CP. This information is important to formulate balanced cost effective feeds. Changes in the essential amino acid (EAA) contents induced by solid state fermentation are given in Table 1. The total EAA content of SBM, GNC, RSM, SFC and GRM was significantly increased $(\mathrm{p}<0.05)$ to a range of $20.19-24.89,16.62-19.56,17.33-21.40$, 15.98-16.92 and $22.10-24.18 \%$ after fermentation compared to the respective control $(19.44,15.48,16.90$, 14.32 and $21.29 \%$ ). 
Table 1. Effect of solid state fermentation on essential amino acid contents ( $\%$ dry matter basis) of plant protein sources ( $\mathrm{n}=6$; mean \pm SD)

\begin{tabular}{|c|c|c|c|c|c|c|c|c|c|c|}
\hline \multirow{2}{*}{ Treatments } & \multicolumn{10}{|c|}{ Essential amino acids (EAA) } \\
\hline & $\mathrm{ARG}$ & HIS & ILE & LEU & LYS & MET & PHE & THR & TRP & VAL \\
\hline SBM & $3.00^{\mathrm{c}} \pm 0.22$ & $1.75^{\mathrm{c}} \pm 0.17$ & $2.73^{c} \pm 0.06$ & $3.93^{\mathrm{c}} \pm 0.08$ & $1.25^{\mathrm{d}} \pm 0.16$ & $0.74^{c} \pm 0.11$ & $2.02^{\mathrm{d}} \pm 0.10$ & $1.71^{\mathrm{c}} \pm 0.12$ & $0.67^{b} \pm 0.05$ & $1.63^{\mathrm{c}} \pm 0.07$ \\
\hline NSBM & $3.67^{b} \pm 0.25$ & $2.06^{\mathrm{a}} \pm 0.14$ & $3.16^{\mathrm{a}} \pm 0.13$ & $4.32^{\mathrm{a}} \pm 0.03$ & $1.72^{\mathrm{b}} \pm 0.19$ & $0.88^{\mathrm{b}} \pm 0.08$ & $2.30^{\mathrm{b}} \pm 0.03$ & $2.01^{\mathrm{a}} \pm 0.10$ & $0.77^{\mathrm{a}} \pm 0.03$ & $2.00^{\mathrm{a}} \pm 0.10$ \\
\hline BSBM & $2.87^{\mathrm{c}} \pm 0.46$ & $1.90^{\mathrm{b}} \pm 0.06$ & $2.72^{\mathrm{c}} \pm 0.12$ & $4.01^{b} \pm 0.08$ & $1.33^{\mathrm{d}} \pm 0.09$ & $0.80^{\mathrm{bc}} \pm 0.05$ & $2.20^{c} \pm 0.05$ & $1.81^{\mathrm{bc}} \pm 0.10$ & $0.71^{\mathrm{b}} \pm 0.02$ & $1.84^{b} \pm 0.07$ \\
\hline FSBM & $4.07^{\mathrm{a}} \pm 0.30$ & $1.95^{\mathrm{ab}} \pm 0.10$ & $2.90^{\mathrm{b}} \pm 0.05$ & $4.01^{b} \pm 0.06$ & $4.01^{\mathrm{a}} \pm 0.22$ & $0.99^{\mathrm{a}} \pm 0.07$ & $2.52^{\mathrm{a}} \pm 0.11$ & $1.91^{\mathrm{ab}} \pm 0.05$ & $0.77 \mathrm{a} \pm 0.04$ & $1.76^{\mathrm{b}} \pm 0.11$ \\
\hline YSBM & $3.85^{\mathrm{ab}} \pm 0.15$ & $1.98^{\mathrm{ab}} \pm 0.13$ & $2.95^{\mathrm{b}} \pm 0.13$ & $3.04^{\mathrm{d}} \pm 0.14$ & $1.47^{b} \pm 0.02$ & $0.84^{b} \pm 0.03$ & $2.47^{\mathrm{a}} \pm 0.15$ & $1.93^{\mathrm{a}} \pm 0.05$ & $0.79^{a} \pm 0.05$ & $1.82^{\mathrm{b}} \pm 0.05$ \\
\hline GNC & $3.04^{\mathrm{d}} \pm 0.21$ & $0.91^{\mathrm{b}} \pm 0.10$ & $1.36^{\mathrm{c}} \pm 0.06$ & $1.09^{\mathrm{c}} \pm 0.02$ & $1.42^{\mathrm{d}} \pm 0.15$ & $0.56^{\mathrm{d}} \pm 0.16$ & $3.00^{c} \pm 0.07$ & $0.95^{\mathrm{d}} \pm 0.07$ & $0.43^{\mathrm{d}} \pm 0.02$ & $2.71^{\mathrm{c}} \pm 0.05$ \\
\hline NGNC & $3.75^{\mathrm{a}} \pm 0.09$ & $1.12^{\mathrm{a}} \pm 0.08$ & $1.51^{\mathrm{bc}} \pm 0.23$ & $1.27^{\mathrm{ab}} \pm 0.09$ & $1.73^{\mathrm{bc}} \pm 0.17$ & $0.71^{\mathrm{bc}} \pm 0.13$ & $3.53^{\mathrm{a}} \pm 0.19$ & $1.07^{\mathrm{c}} \pm 0.10$ & $0.50^{\mathrm{bc}} \pm 0.03$ & $2.71^{\mathrm{c}} \pm 0.01$ \\
\hline BGNC & $3.21^{\mathrm{c}} \pm 0.02$ & $1.00^{\mathrm{b}} \pm 0.02$ & $1.39^{\mathrm{bc}} \pm 0.02$ & $1.22^{b} \pm 0.03$ & $1.54^{\mathrm{cd}} \pm 0.04$ & $0.61^{\mathrm{cd}} \pm 0.00$ & $3.16^{\mathrm{b}} \pm 0.02$ & $1.07^{\mathrm{c}} \pm 0.04$ & $0.49^{c} \pm 0.03$ & $2.95^{\mathrm{a}} \pm 0.03$ \\
\hline FGNC & $3.58^{\mathrm{b}} \pm 0.18$ & $1.09 \mathrm{a} \pm 0.09$ & $1.52^{\mathrm{b}} \pm 0.07$ & $1.11^{\mathrm{c}} \pm 0.04$ & $3.51^{\mathrm{a}} \pm 0.30$ & $1.03^{\mathrm{a}} \pm 0.13$ & $3.10^{\mathrm{bc}} \pm 0.05$ & $1.31^{\mathrm{a}} \pm 0.09$ & $0.52^{\mathrm{ab}} \pm 0.03$ & $2.79^{b} \pm 0.04$ \\
\hline YGNC & $3.77^{\mathrm{a}} \pm 0.13$ & $1.15^{\mathrm{a}} \pm 0.06$ & $1.67^{a} \pm 0.03$ & $1.33^{\mathrm{a}} \pm 0.02$ & $1.77^{\mathrm{b}} \pm 0.10$ & $0.76^{\mathrm{b}} \pm 0.10$ & $3.64^{\mathrm{a}} \pm 0.04$ & $1.18^{\mathrm{b}} \pm 0.04$ & $0.53^{\mathrm{a}} \pm 0.01$ & $2.73^{\mathrm{c}} \pm 0.01$ \\
\hline RSM & $3.62^{c} \pm 0.14$ & $1.73^{\mathrm{c}} \pm 0.15$ & $1.56^{\mathrm{d}} \pm 0.04$ & $2.04^{\mathrm{d}} \pm 0.11$ & $1.10^{\mathrm{d}} \pm 0.15$ & $0.88^{\mathrm{d}} \pm 0.11$ & $0.99^{c} \pm 0.15$ & $2.15^{\mathrm{c}} \pm 0.06$ & $0.47^{c} \pm 0.02$ & $2.36^{\mathrm{c}} \pm 0.11$ \\
\hline NRSM & $3.93^{\mathrm{a}} \pm 0.25$ & $1.97^{\mathrm{a}} \pm 0.09$ & $1.74^{\mathrm{a}} \pm 0.02$ & $2.34^{b} \pm 0.06$ & $1.31^{\mathrm{c}} \pm 0.08$ & $1.04^{\mathrm{c}} \pm 0.06$ & $1.23^{\mathrm{b}} \pm 0.11$ & $2.42^{\mathrm{a}} \pm 0.03$ & $0.53^{\mathrm{a}} \pm 0.01$ & $2.68^{b} \pm 0.06$ \\
\hline BRSM & $3.65^{\mathrm{c}} \pm 0.04$ & $1.82^{\mathrm{b}} \pm 0.03$ & $1.54^{\mathrm{d}} \pm 0.03$ & $2.21^{\mathrm{c}} \pm 0.03$ & $1.11^{\mathrm{d}} \pm 0.03$ & $0.92^{\mathrm{d}} \pm 0.02$ & $0.99^{c} \pm 0.02$ & $2.25^{\mathrm{b}} \pm 0.01$ & $0.52^{\mathrm{b}} \pm 0.01$ & $2.32^{\mathrm{c}} \pm 0.06$ \\
\hline FRSM & $3.82^{\mathrm{ab}} \pm 0.15$ & $1.78^{b c} \pm 0.18$ & $1.66^{\mathrm{b}} \pm 0.05$ & $2.56^{\mathrm{a}} \pm 0.09$ & $3.01^{\mathrm{a}} \pm 0.16$ & $1.41^{\mathrm{a}} \pm 0.10$ & $1.63^{\mathrm{a}} \pm 0.18$ & $2.28^{\mathrm{b}} \pm 0.05$ & $0.53^{\mathrm{a}} \pm 0.02$ & $2.72^{\mathrm{b}} \pm 0.09$ \\
\hline YRSM & $3.76^{\mathrm{bc}} \pm 0.05$ & $1.75^{\mathrm{bc}} \pm 0.06$ & $1.60^{\mathrm{c}} \pm 0.04$ & $2.35^{b} \pm 0.04$ & $2.06^{\mathrm{b}} \pm 0.05$ & $1.17^{\mathrm{b}} \pm 0.07$ & $1.24^{\mathrm{b}} \pm 0.04$ & $2.15^{\mathrm{c}} \pm 0.08$ & $0.53^{\mathrm{a}} \pm 0.01$ & $2.86^{\mathrm{a}} \pm 0.05$ \\
\hline SFC & $1.62^{b} \pm 0.12$ & $0.47^{c} \pm 0.06$ & $3.37^{\mathrm{b}} \pm 0.06$ & $1.46^{\mathrm{c}} \pm 0.08$ & $1.18^{\mathrm{c}} \pm 0.19$ & $1.70^{b} \pm 0.16$ & $1.60^{\mathrm{b}} \pm 0.09$ & $1.02^{\mathrm{c}} \pm 0.11$ & $0.42^{c} \pm 0.04$ & $1.48^{\mathrm{b}} \pm 0.10$ \\
\hline NSFC & $1.97^{\mathrm{a}} \pm 0.16$ & $0.66^{\mathrm{a}} \pm 0.05$ & $3.70^{\mathrm{a}} \pm 0.03$ & $1.69^{\mathrm{b}} \pm 0.04$ & $1.45^{\mathrm{c}} \pm 0.07$ & $1.97^{\mathrm{a}} \pm 0.11$ & $2.02^{\mathrm{a}} \pm 0.19$ & $1.23^{\mathrm{b}} \pm 0.05$ & $0.46^{\mathrm{ab}} \pm 0.01$ & $1.72^{\mathrm{a}} \pm 0.04$ \\
\hline BSFC & $1.68^{\mathrm{b}} \pm 0.03$ & $0.49^{\mathrm{c}} \pm 0.01$ & $3.48^{\mathrm{b}} \pm 0.05$ & $1.51^{\mathrm{c}} \pm 0.02$ & $2.14^{\mathrm{a}} \pm 0.13$ & $1.79^{b} \pm 0.04$ & $1.69^{\mathrm{b}} \pm 0.01$ & $1.18^{\mathrm{b}} \pm 0.02$ & $0.48^{\mathrm{a}} \pm 0.01$ & $1.56^{\mathrm{b}} \pm 0.06$ \\
\hline FSFC & $1.88^{\mathrm{a}} \pm 0.10$ & $0.56^{\mathrm{b}} \pm 0.06$ & $3.37^{\mathrm{b}} \pm 0.06$ & $1.87^{\mathrm{a}} \pm 0.11$ & $2.31^{\mathrm{a}} \pm 0.28$ & $1.77^{\mathrm{b}} \pm 0.09$ & $1.72^{\mathrm{b}} \pm 0.05$ & $1.50^{\mathrm{a}} \pm 0.13$ & $0.44^{\mathrm{bc}} \pm 0.03$ & $1.49^{\mathrm{b}} \pm 0.10$ \\
\hline YSFC & $1.75^{b} \pm 0.04$ & $0.52^{b c} \pm 0.02$ & $3.11^{\mathrm{c}} \pm 0.29$ & $1.65^{b} \pm 0.13$ & $1.74^{b} \pm 0.45$ & $1.70^{\mathrm{b}} \pm 0.05$ & $1.64^{\mathrm{b}} \pm 0.06$ & $1.27^{\mathrm{b}} \pm 0.07$ & $0.46^{\mathrm{ab}} \pm 0.02$ & $1.58^{\mathrm{b}} \pm 0.12$ \\
\hline GRM & $6.19^{b} \pm 0.19$ & $1.30^{\mathrm{d}} \pm 0.10$ & $2.15^{\mathrm{b}} \pm 0.10$ & $1.05^{\mathrm{d}} \pm 0.13$ & $2.06^{\mathrm{c}} \pm 0.16$ & $0.65^{\mathrm{b}} \pm 0.15$ & $2.20^{c} \pm 0.06$ & $2.47^{\mathrm{b}} \pm 0.09$ & $0.79^{\mathrm{d}} \pm 0.04$ & $2.43^{\mathrm{c}} \pm 0.06$ \\
\hline NGRM & $6.24^{b} \pm 0.02$ & $1.42^{\mathrm{bc}} \pm 0.06$ & $2.37^{\mathrm{a}} \pm 0.07$ & $1.19^{\mathrm{bc}} \pm 0.09$ & $2.09^{c} \pm 0.03$ & $0.70^{\mathrm{b}} \pm 0.02$ & $2.57^{\mathrm{a}} \pm 0.10$ & $2.48^{b} \pm 0.03$ & $0.81^{\mathrm{cd}} \pm 0.01$ & $2.61^{\mathrm{ab}} \pm 0.05$ \\
\hline BGRM & $6.27^{b} \pm 0.04$ & $1.38^{\mathrm{cd}} \pm 0.06$ & $2.20^{\mathrm{b}} \pm 0.05$ & $1.10^{\text {cd }} \pm 0.05$ & $2.12^{\mathrm{bc}} \pm 0.04$ & $0.73^{b} \pm 0.06$ & $2.26^{\mathrm{c}} \pm 0.03$ & $2.63^{\mathrm{a}} \pm 0.12$ & $0.87^{\mathrm{b}} \pm 0.06$ & $2.54^{\mathrm{bc}} \pm 0.07$ \\
\hline FGRM & $6.70^{\mathrm{a}} \pm 0.18$ & $1.52^{\mathrm{ab}} \pm 0.13$ & $2.18^{\mathrm{b}} \pm 0.09$ & $1.27^{\mathrm{ab}} \pm 0.06$ & $3.33^{\mathrm{a}} \pm 0.17$ & $1.08^{\mathrm{a}} \pm 0.10$ & $2.27^{\mathrm{c}} \pm 0.09$ & $2.49^{\mathrm{b}} \pm 0.08$ & $0.86^{\mathrm{bc}} \pm 0.04$ & $2.48^{c} \pm 0.12$ \\
\hline YGRM & $6.70^{\mathrm{a}} \pm 0.07$ & $1.54^{\mathrm{a}} \pm 0.06$ & $2.25^{\mathrm{b}} \pm 0.09$ & $1.32^{\mathrm{a}} \pm 0.07$ & $2.23^{\mathrm{b}} \pm 0.06$ & $1.18^{\mathrm{a}} \pm 0.03$ & $2.44^{\mathrm{b}} \pm 0.07$ & $2.62^{\mathrm{a}} \pm 0.04$ & $0.94^{\mathrm{a}} \pm 0.05$ & $2.65^{\mathrm{a}} \pm 0.09$ \\
\hline
\end{tabular}

$\mathrm{N}, \mathrm{B}, \mathrm{F}$ and $\mathrm{Y}$ indicate natural, bacterial, fungal and yeast fermented samples of respective ingredients

Means bearing same superscript in a column between raw and respective fermented samples do not differ significantly ( $\mathrm{p}>0.05)$

Natural fermentation showed significant $(\mathrm{p}<0.05)$ increase in all the EAA compared to the respective control. The increment was more in ARG and VAL in SBM, ARG and LYS in GNC, PHE in RSM, ARG, HIS, LYS, PHE and THR in SFC. The increment of EAA in naturally fermented palm kernel meal and copra meal was also previously reported by Dairo and Fasuyi (2007), but in contrast, Osman (2011) reported a reduced level of certain EAA in natural fermented pearl millet which might be due to the short fermentation period $(12 \mathrm{~h})$. The fungus, A. niger markedly increased the LYS (2.31-4.01\%) irrespective of the ingredients tested. The higher increase of LYS might be due to the higher content of this amino acid in A. niger (6.5-7.8\%) compared to other microbial species (bacterial species contain about 4.5-5.8\%; Ravindra, 2000). The improvement was the highest for ARG in YSBM, LYS in YGNC and YGRM, LEU in YRSM and YSFC than other amino acids in yeast fermentation. Increased EAA contents were also documented in SBM with Bacillus subtilis (Imelda et al., 2008) and S. cerevisiae (Sharawy et al., 2016), RSM with A. niger (Shi et al., 2015). However, Hong et al. (2004) reported that the fermentation of SBM by A. oryzae had no effect on the EAA profiles.
The variations in the increase of essential amino acids during fermentation might be due to the inoculum itself (Shankman, 1943; Christias et al., 1975; Watson, 1976). The increased microbial growth during fermentation resulted in the increase of own amino acid content, which might have reflected in the fermented samples. Microorganism utilised carbohydrates as a source of energy and the bio-conversion of such carbohydrates into microbial protein by intermediary metabolism might also be responsible for the increase observed in the amino acid profiles (Imelda et al., 2008). The increase of amino acids in fermentation might be due to the nitrogen fixing ability, as earlier reported by Lipman (1911) that various strains of fungus, $A$. niger and yeast, $S$. cervesiae assimilated $0.63-2.23$ and $0.76-1.74 \mathrm{mg} 100 \mathrm{cc}^{-1}$ nitrogen respectively. Later Schober (1930) also confirmed the above result for $A$. niger who reported that the fixation was much higher $\left(4 \mathrm{mg} 100 \mathrm{cc}^{-1}\right)$ than the previous reports. But the above results failed to corroborate the results of Allison (1934) who reported negative results for the same species. Recently, Sharma and Kumawat (2011) further confirmed the possible role of $A$. niger and B. japonicum isolates on plant growth in terms of nitrogen fixation, which clearly indicated the role of $A$. niger in nitrogen 
fixation. It would seem that the nitrogen fixation was probably limited and the quantity fixed may be less, but it is of considerable importance for the microbial growth as well as the production of metabolites like amino acids. But the phenomena need to be ascertained by further investigations.

Furthermore, the changes in other nutrients and also dry matter loss could also be a possible reason for the increase of amino acids observed in the present study. About 5-14\% dry matter loss was seen in the present work, which was comparatively less than certain physical and chemical methods (Shi et al., 2015). Almost a similar tendency was noticed for nonessential amino acids (NAA) and the reduction of certain NAA (Table 2) might be attributed to the utilisation of particular amino acids for growth and production of enzymes and other organic compounds by the microorganisms (Imelda et al., 2008).

The quality of protein can be assayed based on the amino acid composition but its suitability to the candidate species depends on its amino acid requirements. Earlier, chemical score was calculated by taking the most limiting amino acid into consideration. Later, EAAI was calculated based on the overall essential amino acid requirements (Akiyama et al., 1991). The quality of fermented ingredients with different inoculums was assessed by calculating EAAI for $P$. vannamei for optimising the fermentation method. The fungal fermentation resulted in the best improvement of most limiting indispensable amino acids like LYS, MET and TRP which in turn resulted in the improvement of EAAI for $P$. vannamei. This higher improvement of EAA might be due to its higher contents in $A$. niger compared to other inoculums used in the present study. The same was confirmed by Christias et al. (1975) who reported that the total EAA content was $102.24 \mu \mathrm{M} 100 \mathrm{mg}$ dry weight ${ }^{-1}$ in $A$. niger, whereas it was $8.81 \mu \mathrm{M} 100 \mathrm{mg}^{\text {dry weight }}{ }^{-1}$ in $S$. cerevisea (Watson, 1976) and $0.10 \mu \mathrm{M} 100 \mathrm{mg}$ dry weight ${ }^{-1}$ in Lactobacillus sp. (Shankman, 1943). The reflection of higher content of EAA of fungus in the respective treated samples might be responsible for such improvement in EAAI than other treatments. Among the ingredients tested, the lowest EAAI was observed in FGRM followed by FSFC and FGNC (Fig. 1). The best improvement of EAAI was observed with fungal fermentation in FRSM $(0.824 \pm 0.015$ to $0.916 \pm 0.003)$. The results clearly indicate

Table 2. Effect of solid state fermentation on essential amino acid contents $(\%$ dry matter basis) of plant protein sources ( $\mathrm{n}=6$; mean \pm SD)

\begin{tabular}{|c|c|c|c|c|c|c|c|c|}
\hline \multirow{2}{*}{ Treatments } & \multicolumn{8}{|c|}{ Non-essential amino acids (NAA) } \\
\hline & ALA & ASP & CYT & GLU & GLY & $\mathrm{PRO}$ & SER & TYR \\
\hline SBM & $3.32^{\mathrm{b}} \pm 0.11$ & $5.03^{\mathrm{c}} \pm 0.07$ & $0.80^{\mathrm{c}} \pm 0.06$ & $7.95^{\mathrm{b}} \pm 0.10$ & $1.07^{\mathrm{bc}} \pm 0.09$ & $2.74^{\mathrm{bc}} \pm 0.10$ & $2.51^{\mathrm{d}} \pm 0.19$ & $2.34^{\mathrm{c}} \pm 0.10$ \\
\hline NSBM & $3.74^{\mathrm{a}} \pm 0.08$ & $5.58^{\mathrm{a}} \pm 0.09$ & $0.98^{\mathrm{b}} \pm 0.02$ & $8.17^{\mathrm{a}} \pm 0.05$ & $1.17^{\mathrm{a}} \pm 0.11$ & $2.88^{\mathrm{a}} \pm 0.11$ & $3.28^{\mathrm{a}} \pm 0.09$ & $2.47^{\mathrm{ab}} \pm 0.07$ \\
\hline BSBM & $2.94^{\mathrm{c}} \pm 0.15$ & $5.22^{\mathrm{b}} \pm 0.09$ & $0.85^{\mathrm{c}} \pm 0.03$ & $8.20^{\mathrm{a}} \pm 0.07$ & $1.03^{\mathrm{c}} \pm 0.04$ & $2.79^{\mathrm{ab}} \pm 0.04$ & $2.62^{\mathrm{d}} \pm 0.12$ & $2.54^{\mathrm{a}} \pm 0.09$ \\
\hline FSBM & $3.42^{\mathrm{b}} \pm 0.10$ & $5.25^{\mathrm{b}} \pm 0.08$ & $1.07^{\mathrm{a}} \pm 0.12$ & $8.02^{b} \pm 0.11$ & $1.19^{\mathrm{a}} \pm 0.12$ & $2.67^{c} \pm 0.12$ & $3.13^{\mathrm{b}} \pm 0.15$ & $2.43^{\mathrm{abc}} \pm 0.08$ \\
\hline YSBM & $3.65^{\mathrm{a}} \pm 0.10$ & $5.54^{\mathrm{a}} \pm 0.11$ & $1.00^{\mathrm{ab}} \pm 0.05$ & $8.26^{\mathrm{a}} \pm 0.13$ & $1.14^{\mathrm{ab}} \pm 0.02$ & $2.82^{\mathrm{ab}} \pm 0.04$ & $2.74^{\mathrm{c}} \pm 0.09$ & $2.37^{\mathrm{bc}} \pm 0.20$ \\
\hline GNC & $2.02^{\mathrm{c}} \pm 0.05$ & $3.24^{\mathrm{e}} \pm 0.05$ & $0.61^{\mathrm{d}} \pm 0.13$ & $6.27^{\mathrm{e}} \pm 0.19$ & $2.03^{\mathrm{b}} \pm 0.16$ & $1.68^{\mathrm{c}} \pm 0.11$ & $2.13^{\mathrm{c}} \pm 0.18$ & $3.54^{\mathrm{b}} \pm 0.06$ \\
\hline NGNC & $2.16^{\mathrm{b}} \pm 0.01$ & $3.92^{\mathrm{b}} \pm 0.06$ & $1.01^{\mathrm{b}} \pm 0.09$ & $7.36^{\mathrm{a}} \pm 0.10$ & $2.36^{\mathrm{a}} \pm 0.05$ & $1.64^{\mathrm{c}} \pm 0.02$ & $2.65^{\mathrm{a}} \pm 0.05$ & $3.59^{\mathrm{b}} \pm 0.05$ \\
\hline BGNC & $2.05^{\mathrm{c}} \pm 0.01$ & $3.42^{\mathrm{d}} \pm 0.06$ & $0.77^{\mathrm{c}} \pm 0.04$ & $6.40^{\mathrm{d}} \pm 0.06$ & $2.36^{\mathrm{a}} \pm 0.21$ & $1.59^{c} \pm 0.06$ & $2.53^{\mathrm{ab}} \pm 0.09$ & $3.56^{\mathrm{b}} \pm 0.08$ \\
\hline FGNC & $2.14^{\mathrm{b}} \pm 0.09$ & $4.19^{\mathrm{a}} \pm 0.03$ & $1.11^{\mathrm{a}} \pm 0.09$ & $7.09^{b} \pm 0.15$ & $2.44^{\mathrm{a}} \pm 0.12$ & $2.20^{\mathrm{b}} \pm 0.13$ & $2.48^{\mathrm{b}} \pm 0.15$ & $3.56^{\mathrm{b}} \pm 0.07$ \\
\hline YGNC & $2.29^{\mathrm{a}} \pm 0.04$ & $3.72^{\mathrm{c}} \pm 0.07$ & $0.93^{\mathrm{b}} \pm 0.07$ & $6.57^{\mathrm{c}} \pm 0.12$ & $2.32^{\mathrm{a}} \pm 0.23$ & $2.43^{\mathrm{a}} \pm 0.03$ & $1.82^{\mathrm{d}} \pm 0.16$ & $3.81^{\mathrm{a}} \pm 0.06$ \\
\hline RSM & $2.69^{c} \pm 0.09$ & $2.24^{\mathrm{d}} \pm 0.05$ & $1.12^{\mathrm{d}} \pm 0.11$ & $5.10^{\mathrm{b}} \pm 0.07$ & $3.21^{\mathrm{b}} \pm 0.05$ & $2.32 \mathrm{z}^{\mathrm{c}} \pm 0.09$ & $2.49^{\mathrm{b}} \pm 0.09$ & $1.72^{\mathrm{a}} \pm 0.06$ \\
\hline NRSM & $2.83^{\mathrm{ab}} \pm 0.10$ & $2.65^{\mathrm{a}} \pm 0.05$ & $1.59^{\mathrm{c}} \pm 0.03$ & $5.30^{\mathrm{a}} \pm 0.09$ & $3.35^{\mathrm{a}} \pm 0.09$ & $2.52^{\mathrm{a}} \pm 0.08$ & $2.21^{\mathrm{c}} \pm 0.06$ & $1.72^{\mathrm{a}} \pm 0.09$ \\
\hline BRSM & $2.61^{\mathrm{d}} \pm 0.08$ & $2.32^{\mathrm{c}} \pm 0.01$ & $1.04^{\mathrm{e}} \pm 0.02$ & $5.10^{\mathrm{b}} \pm 0.11$ & $3.22^{\mathrm{b}} \pm 0.15$ & $2.39^{b c} \pm 0.12$ & $2.44^{\mathrm{b}} \pm 0.04$ & $1.69^{\mathrm{a}} \pm 0.10$ \\
\hline FRSM & $2.84^{\mathrm{a}} \pm 0.08$ & $2.54^{\mathrm{b}} \pm 0.03$ & $1.79^{\mathrm{b}} \pm 0.09$ & $5.11^{\mathrm{b}} \pm 0.05$ & $3.31^{\mathrm{ab}} \pm 0.15$ & $2.54^{\mathrm{a}} \pm 0.05$ & $2.67^{\mathrm{a}} \pm 0.09$ & $1.82^{\mathrm{a}} \pm 0.07$ \\
\hline YRSM & $2.76^{\mathrm{bc}} \pm 0.06$ & $2.57^{\mathrm{b}} \pm 0.08$ & $2.02^{\mathrm{a}} \pm 0.04$ & $5.25^{\mathrm{a}} \pm 0.11$ & $3.00^{c} \pm 0.05$ & $2.47^{\mathrm{ab}} \pm 0.07$ & $2.46^{\mathrm{b}} \pm 0.10$ & $1.74^{\mathrm{a}} \pm 0.02$ \\
\hline $\mathrm{SFC}$ & $1.09^{c} \pm 0.07$ & $1.63^{\mathrm{c}} \pm 0.08$ & $1.23^{\mathrm{ab}} \pm 0.08$ & $6.95^{\mathrm{a}} \pm 0.09$ & $1.09^{\mathrm{d}} \pm 0.09$ & $1.33^{\mathrm{b}} \pm 0.10$ & $1.40^{\mathrm{b}} \pm 0.06$ & $1.64^{\mathrm{bc}} \pm 0.05$ \\
\hline NSFC & $1.18^{\mathrm{bc}} \pm 0.18$ & $1.93^{\mathrm{a}} \pm 0.01$ & $1.09^{\mathrm{d}} \pm 0.06$ & $4.89^{a} \pm 3.24$ & $1.23^{\mathrm{bc}} \pm 0.10$ & $1.24^{\mathrm{c}} \pm 0.02$ & $1.70^{\mathrm{a}} \pm 0.06$ & $1.58^{\mathrm{c}} \pm 0.07$ \\
\hline BSFC & $1.06^{\mathrm{c}} \pm 0.03$ & $1.71^{\mathrm{b}} \pm 0.06$ & $1.16^{\mathrm{c}} \pm 0.02$ & $6.94^{\mathrm{a}} \pm 0.07$ & $1.55^{\mathrm{a}} \pm 0.15$ & $1.16^{\mathrm{d}} \pm 0.04$ & $1.11^{\mathrm{c}} \pm 0.05$ & $1.64^{\mathrm{bc}} \pm 0.02$ \\
\hline FSFC & $1.24^{\mathrm{bc}} \pm 0.08$ & $1.89^{\mathrm{a}} \pm 0.07$ & $1.29^{\mathrm{a}} \pm 0.07$ & $6.98^{\mathrm{a}} \pm 0.09$ & $1.32^{\mathrm{b}} \pm 0.10$ & $1.57^{\mathrm{a}} \pm 0.12$ & $1.51^{\mathrm{b}} \pm 0.12$ & $1.71^{\mathrm{b}} \pm 0.09$ \\
\hline YSFC & $1.52^{\mathrm{a}} \pm 0.07$ & $1.70^{\mathrm{b}} \pm 0.09$ & $1.18^{\mathrm{bc}} \pm 0.03$ & $7.18^{\mathrm{a}} \pm 0.12$ & $1.16^{\mathrm{cd}} \pm 0.01$ & $1.40^{\mathrm{b}} \pm 0.08$ & $1.17^{\mathfrak{c}} \pm 0.14$ & $1.80^{\mathrm{a}} \pm 0.13$ \\
\hline GRM & $1.61^{\mathrm{d}} \pm 0.07$ & $4.31^{\mathrm{c}} \pm 0.05$ & $0.71^{\mathrm{c}} \pm 0.15$ & $6.54^{\mathrm{b}} \pm 0.07$ & $2.77^{\mathrm{c}} \pm 0.12$ & $2.60^{\mathrm{bc}} \pm 0.07$ & $3.59^{\mathrm{e}} \pm 0.21$ & $1.91^{\mathrm{c}} \pm 0.09$ \\
\hline NGRM & $1.92^{\mathrm{b}} \pm 0.07$ & $4.63^{\mathrm{a}} \pm 0.03$ & $0.90^{\mathrm{b}} \pm 0.01$ & $6.61^{b} \pm 0.02$ & $3.01^{\mathrm{b}} \pm 0.05$ & $2.79 \mathrm{a} \pm 0.03$ & $4.14^{\mathrm{c}} \pm 0.10$ & $2.25^{\mathrm{a}} \pm 0.16$ \\
\hline BGRM & $1.77^{\mathrm{c}} \pm 0.06$ & $4.07^{\mathrm{d}} \pm 0.04$ & $0.85^{\mathrm{b}} \pm 0.03$ & $6.58^{\mathrm{b}} \pm 0.12$ & $2.46^{\mathrm{d}} \pm 0.08$ & $2.84^{\mathrm{a}} \pm 0.05$ & $3.81^{\mathrm{d}} \pm 0.08$ & $2.05^{b c} \pm 0.11$ \\
\hline FGRM & $1.93^{\mathrm{b}} \pm 0.10$ & $4.38^{c} \pm 0.05$ & $1.18^{\mathrm{a}} \pm 0.15$ & $6.81^{\mathrm{a}} \pm 0.05$ & $3.22^{\mathrm{a}} \pm 0.15$ & $2.65^{\mathrm{b}} \pm 0.07$ & $4.78^{\mathrm{a}} \pm 0.18$ & $2.18^{\mathrm{ab}} \pm 0.07$ \\
\hline YGRM & $2.29^{\mathrm{a}} \pm 0.14$ & $4.55^{\mathrm{b}} \pm 0.10$ & $0.93^{\mathrm{b}} \pm 0.04$ & $6.77^{\mathrm{a}} \pm 0.05$ & $3.10^{\mathrm{b}} \pm 0.03$ & $2.54^{\mathrm{c}} \pm 0.08$ & $4.44^{\mathrm{b}} \pm 0.12$ & $2.18^{\mathrm{ab}} \pm 0.16$ \\
\hline
\end{tabular}

$\mathrm{N}, \mathrm{B}, \mathrm{F}$ and $\mathrm{Y}$ indicate natural, bacterial, fungal and yeast fermented samples of respective ingredients

Means bearing same superscript in a column between raw and respective fermented samples do not differ significantly ( $\mathrm{p}>0.05$ ) 


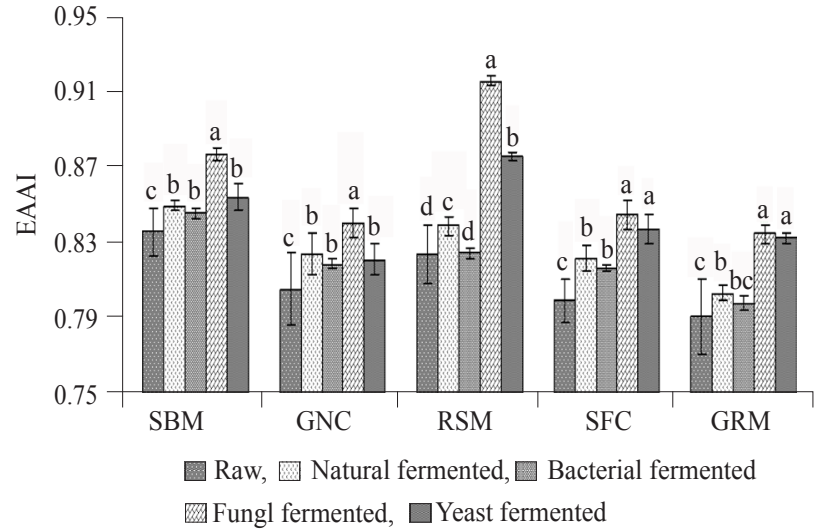

Fig. 1. Effect of solid state fermentation on essential amino acid index (EAAI) in plant protein sources

that the amino acid composition varies not only with the inoculums used for fermentation but also based on the substrate.

\section{Effect of SSF on fiber fractions}

The effect of different methods of SSF on fiber fractions of plant protein sources are shown in
Table 3. The level of NDF was 11.98, 21.54, 26.58, 43.86 and $19.71 \%$ in SBM, GNC, RSM, SFC and GRM and was reduced to a range of $11.47-11.85, \quad 20.95-21.29, \quad 25.30-25.33, \quad 40.36-41.09$ and $11.59-15.34 \%$ by fungal and yeast fermentation, respectively. The percentage of reduction was found to be highest in GRM (22-41\%) compared to other ingredients (1-8\%). Similarly, fungal and yeast fermented GRM showed the highest ADF reduction (around 15\%), whereas it was between 0.2 and $5.4 \%$ for other ingredients. This might be due to the differences in the production of fibrolytic enzymes according to the substrate and microorganism during fermentation (Shi et al., 2015).

Fungal fermentation showed almost similar reduction of cellulose (19.80-26.88\%) among all the ingredients tested but the reduction $(\mathrm{p}<0.05)$ varied between ingredients in yeast fermentation (5.25-17.02\%). It clearly indicates that the production of individual fibrolytic enzymes had differed according to the strain and substrate used for fermentation. Hemicellulose was reduced by $2.5-2.7 \%$ in SBM, 2.0-6.3\% in GNC, 6.4-11.0\% in RSM, $10.1-21.8 \%$ in SFC and $25.7-62.0 \%$ in GRM respectively.

Table 3. Effect of solid state fermentation on fiber fractions ( $\%$ dry matter basis) of plant protein sources $(n=6$; mean \pm SD)

\begin{tabular}{|c|c|c|c|c|c|}
\hline \multirow{2}{*}{ Treatments } & \multicolumn{5}{|c|}{ Fiber fractions } \\
\hline & NDF & $\mathrm{ADF}$ & Cellulose & Hemicellulose & Lignin \\
\hline SBM & $11.98^{\mathrm{c}} \pm 0.16$ & $7.82^{b} \pm 0.25$ & $6.96^{\mathrm{a}} \pm 0.21$ & $4.15^{\mathrm{c}} \pm 0.30$ & $0.86^{\mathrm{a}} \pm 0.05$ \\
\hline NSBM & $13.25^{\mathrm{b}} \pm 0.17$ & $8.09^{\mathrm{a}} \pm 0.04$ & $6.99^{\mathrm{a}} \pm 0.07$ & $5.16^{\mathrm{b}} \pm 0.21$ & $0.92^{\mathrm{a}} \pm 0.04$ \\
\hline BSBM & $15.85^{\mathrm{a}} \pm 0.06$ & $8.31^{\mathrm{a}} \pm 0.06$ & $7.01^{\mathrm{a}} \pm 0.17$ & $7.54^{\mathrm{a}} \pm 0.00$ & $0.90^{\mathrm{a}} \pm 0.07$ \\
\hline FSBM & $11.47^{\mathrm{d}} \pm 0.08$ & $7.39^{c} \pm 0.17$ & $5.58^{\mathrm{c}} \pm 0.24$ & $4.01^{\mathrm{c}} \pm 0.01$ & $0.73^{\mathrm{b}} \pm 0.04$ \\
\hline YSBM & $11.85^{\mathrm{c}} \pm 0.23$ & $7.81^{\mathrm{b}} \pm 0.41$ & $6.21^{\mathrm{b}} \pm 0.55$ & $4.05^{\mathrm{c}} \pm 0.42$ & $0.85^{\mathrm{a}} \pm 0.12$ \\
\hline GNC & $21.54^{\mathrm{b}} \pm 0.23$ & $13.90^{\mathrm{b}} \pm 0.46$ & $8.75^{\mathrm{b}} \pm 0.48$ & $7.64^{b} \pm 0.79$ & $5.15^{\mathrm{a}} \pm 0.01$ \\
\hline NGNC & $24.69^{\mathrm{a}} \pm 0.06$ & $16.19^{\mathrm{a}} \pm 0.08$ & $10.51^{\mathrm{a}} \pm 0.01$ & $8.50^{\mathrm{a}} \pm 0.14$ & $5.28^{\mathrm{a}} \pm 0.12$ \\
\hline BGNC & $24.96^{\mathrm{a}} \pm 0.35$ & $16.43^{\mathrm{a}} \pm 0.43$ & $10.79^{\mathrm{a}} \pm 0.40$ & $8.54^{\mathrm{a}} \pm 0.78$ & $5.22^{\mathrm{a}} \pm 0.03$ \\
\hline FGNC & $20.95^{\mathrm{c}} \pm 0.33$ & $13.80^{\mathrm{b}} \pm 0.37$ & $6.85^{\mathrm{d}} \pm 0.33$ & $7.15^{\mathrm{b}} \pm 0.67$ & $5.10^{\mathrm{a}} \pm 0.09$ \\
\hline YGNC & $21.29^{\mathrm{bc}} \pm 0.58$ & $13.87^{\mathrm{b}} \pm 0.61$ & $7.79^{c} \pm 0.49$ & $7.42^{b} \pm 0.66$ & $5.12^{\mathrm{a}} \pm 0.27$ \\
\hline RSM & $26.58^{\mathrm{c}} \pm 0.11$ & $19.34^{\mathrm{b}} \pm 0.33$ & $8.62^{b} \pm 0.54$ & $7.25^{\mathrm{bc}} \pm 0.36$ & $10.72^{\mathrm{a}} \pm 0.21$ \\
\hline NRSM & $29.00^{\mathrm{a}} \pm 0.33$ & $20.78^{\mathrm{a}} \pm 0.09$ & $9.48^{\mathrm{a}} \pm 0.42$ & $8.22^{\mathrm{a}} \pm 0.29$ & $10.95^{\mathrm{a}} \pm 0.49$ \\
\hline BRSM & $28.14^{\mathrm{b}} \pm 0.42$ & $20.74^{\mathrm{a}} \pm 0.42$ & $9.49^{\mathrm{a}} \pm 0.20$ & $7.40^{\mathrm{b}} \pm 0.60$ & $10.90^{\mathrm{a}} \pm 0.29$ \\
\hline FRSM & $25.30^{\mathrm{d}} \pm 0.70$ & $18.51^{\mathrm{d}} \pm 0.02$ & $7.63^{c} \pm 0.06$ & $6.80^{\mathrm{cd}} \pm 0.68$ & $8.48^{\mathrm{c}} \pm 0.01$ \\
\hline YRSM & $25.33^{\mathrm{d}} \pm 0.03$ & $18.90^{\mathrm{c}} \pm 0.24$ & $8.62^{b} \pm 0.40$ & $6.43^{\mathrm{d}} \pm 0.21$ & $9.58^{\mathrm{b}} \pm 0.10$ \\
\hline $\mathrm{SFC}$ & $43.86^{\mathrm{c}} \pm 0.52$ & $27.59^{c} \pm 0.20$ & $19.77^{\mathrm{b}} \pm 0.16$ & $16.27^{\mathrm{b}} \pm 0.44$ & $7.82^{\mathrm{c}} \pm 0.05$ \\
\hline NSFC & $46.17^{\mathrm{a}} \pm 0.15$ & $29.28^{\mathrm{a}} \pm 0.17$ & $20.11^{\mathrm{a}} \pm 0.27$ & $16.89^{\mathrm{a}} \pm 0.32$ & $8.95^{\mathrm{a}} \pm 0.09$ \\
\hline BSFC & $45.65^{\mathrm{b}} \pm 0.48$ & $29.19^{\mathrm{a}} \pm 0.13$ & $20.06^{\mathrm{a}} \pm 0.13$ & $16.46^{\mathrm{ab}} \pm 0.47$ & $8.64^{\mathrm{b}} \pm 0.11$ \\
\hline FSFC & $40.36^{\mathrm{e}} \pm 0.37$ & $25.72^{\mathrm{d}} \pm 0.29$ & $15.60^{\mathrm{d}} \pm 0.27$ & $14.64^{\mathrm{c}} \pm 0.56$ & $7.69^{c} \pm 0.09$ \\
\hline YSFC & $41.09^{\mathrm{d}} \pm 0.22$ & $28.40^{\mathrm{b}} \pm 0.37$ & $18.72^{\mathrm{c}} \pm 0.17$ & $12.69^{\mathrm{d}} \pm 0.59$ & $8.74^{\mathrm{b}} \pm 0.23$ \\
\hline GRM & $19.71^{\mathrm{b}} \pm 0.30$ & $9.01^{\mathrm{b}} \pm 0.17$ & $7.90^{\mathrm{b}} \pm 0.25$ & $10.70^{\mathrm{b}} \pm 0.53$ & $1.11^{\mathrm{b}} \pm 0.09$ \\
\hline NGRM & $20.85^{\mathrm{a}} \pm 0.22$ & $9.81^{\mathrm{a}} \pm 0.17$ & $8.08^{\mathrm{ab}} \pm 0.17$ & $11.53^{\mathrm{a}} \pm 0.06$ & $1.38^{\mathrm{a}} \pm 0.15$ \\
\hline BGRM & $20.86^{a} \pm 0.65$ & $10.08^{\mathrm{a}} \pm 0.92$ & $8.44^{\mathrm{a}} \pm 0.90$ & $11.25^{\mathrm{a}} \pm 0.31$ & $1.28^{\mathrm{ab}} \pm 0.33$ \\
\hline FGRM & $11.59^{\mathrm{d}} \pm 0.09$ & $7.66^{c} \pm 0.11$ & $5.72^{\mathrm{d}} \pm 0.23$ & $3.93^{\mathrm{d}} \pm 0.05$ & $0.44^{\mathrm{c}} \pm 0.04$ \\
\hline YGRM & $15.34^{\mathrm{c}} \pm 0.40$ & $7.70^{c} \pm 0.04$ & $6.53^{\mathrm{c}} \pm 0.05$ & $7.96^{\mathrm{c}} \pm 0.43$ & $0.47^{\mathrm{c}} \pm 0.04$ \\
\hline
\end{tabular}

$\mathrm{N}, \mathrm{B}, \mathrm{F}$ and $\mathrm{Y}$ indicate natural, bacterial, fungal and yeast fermented samples of respective ingredients Means bearing same superscript in a column between raw and respective fermented samples do not differ significantly ( $\mathrm{p}>0.05$ ) NDF - Neutral detergent fiber, ADF - Acid detergent fiber 
Fungal fermented RSM showed significant reduction $(p<0.05)$ of lignin $(10.72$ to $8.48 \%)$ whereas it was not much affected in other ingredients tested. The reduction in fiber fractions after fermentation was associated with the production of fibrolytic enzymes by the inherent microorganisms (Shi et al., 2015). Whereas in bacterial and natural fermentation, fiber fractions were not reduced, which might be due to the lack of production of respective enzymes by the microorganisms or unsuitable selection of microorganisms responsible for fiber degradation based on substrate or the utilisation of easily digestible soluble carbohydrates by the growing microorganism and leaving the indigestible fiber content (Amanullah et al., 2014).

\section{Effect of SSF on anti-nutrients}

The level of anti-nutrients of both raw and fermented plant protein sources are presented in Table 4. Trypsin inhibitor was identified only in SBM and GRM and was reduced in all the fermentation methods. The reduction of trypsin inhibitor was mainly attributed to the application of heat during autoclaving (Hong et al., 2004), but its reduction in natural fermented samples indicated the role of microorganisms in degrading trypsin inhibitor.
Roychaudhuri et al. (2004) inferred that the trypsin inhibitor in SBM belonging to the family of anti-parallel $\beta$-sheet proteins renature and thus cannot be completely removed by processing methods. Though, trypsin inhibitor in GRM also belongs to the same family, its level was reduced to below detectable range after treatment and the same was supported by Mubarak (2005) in mung bean.

Saponin was significantly $(\mathrm{p}<0.05)$ reduced by $65.8-79.1 \%$ in SBM, 38.6-49.0\% in GNC, $24.8-67.7 \%$ in SFC and $56.7-62.2 \%$ in GRM due to solid state fermentation. The reduction of saponin content might be due to the degradation of saponin into sapogenin and sugar moieties by the microbial enzyme glycosidase (Makkar and Becker, 1997). The phytic acid reduction was better with bacterial fermentation (40.5-67.6\%) compared to other treatments (17.9-53.8\%). The reduction of phytic acid was due to the activity of the endogenous phytase enzyme during fermentation, which hydrolyse the phytic acid into inositol and orthophosphate (Reddy and Peirson, 1994). The reduction of tannin content was found to be high in GNC (74.9-83.5\%), whereas it was $<42.7 \%$ for other ingredients. Production of enzyme tannase or

Table 4. Effect of solid state fermentation on the level of anti-nutrients ( $\mathrm{mg} 100 \mathrm{~g}$ dry matter basis $\left.{ }^{-1}\right)$ of plant protein sources $(\mathrm{n}=6 ; \mathrm{mean} \pm \mathrm{SD})$

\begin{tabular}{|c|c|c|c|c|c|c|}
\hline \multirow{2}{*}{ Treatments } & \multicolumn{6}{|c|}{ Anti-nutrients } \\
\hline & Trypsin inhibitor & Saponin & Phytic acid & Tannin & Glucosinolates & Guar gum (\%) \\
\hline SBM & $241.05^{\mathrm{a}} \pm 2.99$ & $1003.16^{\mathrm{a}} \pm 0.50$ & $1335.67^{a} \pm 23.23$ & - & - & - \\
\hline NSBM & $87.15^{b} \pm 98.77$ & $343.14^{\mathrm{b}} \pm 14.61$ & $1029.41^{b} \pm 44.82$ & - & - & - \\
\hline BSBM & nd & $259.43^{\mathrm{c}} \pm 38.67$ & $611.47^{\mathrm{e}} \pm 63.23$ & - & - & - \\
\hline FSBM & $13.97^{c} \pm 1.95$ & $209.52^{\mathrm{d}} \pm 4.81$ & $653.27^{\mathrm{d}} \pm 17.30$ & - & - & - \\
\hline YSBM & $18.15^{\mathrm{c}} \pm 3.82$ & $229.58^{\mathrm{d}} \pm 4.78$ & $792.31^{\mathrm{c}} \pm 37.25$ & - & - & - \\
\hline GNC & - & $736.17^{\mathrm{a}} \pm 58.10$ & $1033.16^{\mathrm{a}} \pm 25.70$ & $1756.02^{\mathrm{a}} \pm 85.24$ & - & - \\
\hline NGNC & - & $451.99^{b} \pm 69.02$ & $847.76^{\mathrm{b}} \pm 64.68$ & $417.54^{b} \pm 33.84$ & - & - \\
\hline BGNC & - & $381.15^{\mathrm{c}} \pm 33.84$ & $614.49^{\mathrm{d}} \pm 38.49$ & $382.95^{\mathrm{b}} \pm 10.29$ & - & - \\
\hline FGNC & - & $375.66^{\mathrm{c}} \pm 38.40$ & $646.49^{\mathrm{d}} \pm 29.75$ & $288.95^{\mathrm{c}} \pm 7.58$ & - & - \\
\hline YGNC & - & $429.48^{\mathrm{bc}} \pm 21.48$ & $707.93^{\mathrm{c}} \pm 59.08$ & $440.96^{b} \pm 56.60$ & - & - \\
\hline RSM & - & - & $2745.44^{\mathrm{a}} \pm 134.03$ & $889.43^{\mathrm{a}} \pm 29.88$ & $313.16^{\mathrm{a}} \pm 11.77$ & - \\
\hline NRSM & - & - & $1850.99^{b} \pm 110.92$ & $791.07^{b} \pm 30.52$ & $273.95^{\mathrm{b}} \pm 15.31$ & - \\
\hline BRSM & - & - & $890.76^{\mathrm{d}} \pm 22.93$ & $667.54^{\mathrm{c}} \pm 2.87$ & $238.94^{\mathrm{c}} \pm 7.78$ & - \\
\hline FRSM & - & - & $897.28^{d} \pm 22.93$ & $509.89^{\mathrm{d}} \pm 26.24$ & $182.48^{\mathrm{e}} \pm 7.77$ & - \\
\hline YRSM & - & - & $1216.72^{\mathrm{c}} \pm 98.34$ & $510.19^{d} \pm 15.20$ & $210.70^{\mathrm{d}} \pm 13.92$ & - \\
\hline SFC & - & $641.52^{\mathrm{a}} \pm 39.57$ & - & $878.55^{\mathrm{a}} \pm 17.70$ & - & - \\
\hline NSFC & - & $482.25^{\mathrm{b}} \pm 2.3 .70$ & - & $581.74^{\mathrm{c}} \pm 34.40$ & - & - \\
\hline BSFC & - & $254.16^{\mathrm{c}} \pm 37.89$ & - & $694.54^{\mathrm{b}} \pm 49.04$ & - & - \\
\hline FSFC & - & $217.07^{\mathrm{d}} \pm 23.68$ & - & $610.36^{c} \pm 9.23$ & - & - \\
\hline YSFC & - & $207.01^{\mathrm{d}} \pm 18.99$ & - & $610.86^{\mathrm{c}} \pm 23.92$ & - & - \\
\hline GRM & $81.06^{\mathrm{a}} \pm 8.37$ & $2552.82^{\mathrm{a}} \pm 49.21$ & $2567.49^{\mathrm{a}} \pm 156.44$ & $392.33^{\mathrm{a}} \pm 7.96$ & - & $10.99^{\mathrm{a}} \pm 0.53$ \\
\hline NGRM & $38.90^{\mathrm{b}} \pm 6.76$ & $1016.97^{c} \pm 70.69$ & $1966.84^{b} \pm 16.98$ & $369.64^{b} \pm 14.77$ & - & $10.16^{\mathrm{a}} \pm 1.25$ \\
\hline BGRM & nd & $1001.90^{c} \pm 66.03$ & $1113.69^{\mathrm{d}} \pm 15.76$ & $356.22^{\mathrm{c}} \pm 6.25$ & - & $10.22^{\mathrm{a}} \pm 0.58$ \\
\hline FGRM & nd & $964.72^{\mathrm{c}} \pm 33.37$ & $1187.15^{\mathrm{d}} \pm 27.57$ & $333.53^{\mathrm{d}} \pm 12.06$ & - & $10.17^{\mathrm{a}} \pm 0.58$ \\
\hline YGRM & nd & $1105.00^{\mathrm{b}} \pm 52.02$ & $1632.30^{c} \pm 27.19$ & $320.70^{\mathrm{d}} \pm 0.96$ & - & $10.27^{\mathrm{a}} \pm 0.87$ \\
\hline
\end{tabular}

$\mathrm{N}, \mathrm{B}, \mathrm{F}$ and $\mathrm{Y}$ indicate natural, bacterial, fungal and yeast fermented samples of respective ingredients Means bearing same superscript in a column between row and respective fermented samples do not differ significantly ( $\mathrm{p}>0.05$ ) nd: Not detected 
microbial phenyl oxidase action might be responsible for the reduction of tannin content in the treated samples (Emambux and Taylor, 2003).

Glucosinolates were reduced by $41.7 \%$ by $A$. niger and the reduction was $12.5-32.7 \%$ with other treatments. Reduced glucosinolates mainly attributed to the utilisation of glucose and sulphur moieties during fermentation (Shi et al., 2015). The reduction of gum content in guar meal due to fermentation was comparatively lower than other anti-nutrients.

All the four fermentation methodologies showed a positive effect on EAA and better EAAI was observed with fungal fermentation. Anti-nutrients were also effectively reduced by the specific inoculums rather than the natural fermentation. The plant ingredients inoculated with fungal and yeast showed reduction of fiber fractions. From the present investigation, it was concluded that specific inoculum fermentation especially fungal and yeast methods can be considered as a potential processing technique to produce nutrient enriched products which are of industrial importance. This data will pave the way for higher fishmeal replacement using fermented ingredients in shrimp feed formulations.

\section{Acknowledgements}

Authors would like to thank Dr. K.K. Vijayan, Director, ICAR-Central Institute of Brackishwater Aquaculture, Chennai for granting the necessary facilities. This work was financially supported by the ICAR through the National Innovation in Climate Resilient Agriculture (NICRA) project.

\section{References}

Akiyama, D. M., Dominy, W. G. and Lawrence, A. L. 1991. Penaeid shrimp nutrition for the commercial feed industry. In: Fast, A. L. and Lester, L. J. (Eds.), Marine shrimp culture: Principles and practices. Elsevier Science Publishers BV, Amsterdam, The Netherlands, p. 535-568.

Allison, F. E. 1934. Nitrogen fixation studies with fungi and actinomyces. J. Agri. Res., 49: 1115-1123.

Amanullah, S. M., Kim, D. H., Lee, H. J., Joo, Y. H., Kim, S. B. and Kim, S. C. 2014. Effects of microbial additives on chemical composition and fermentation characteristics of barley silage. Asian Australas J. Anim. Sci., 27: 511-517.

AOAC 1997. Official methods of analysis. $18^{\text {th }}$ edn. Association of Official Analytical Chemists, Benjamin Franklin Station, Washington DC, USA.

Christias, C., Couvaraki, C., Georgopoulos, S. G., Macris, B. and Vomvoyanni, V. 1975. Protein content and amino acid composition of certain fungi evaluated for microbial protein production. Applied Microbiol., 250-254.
Dairo, F. A. S. and Fasuyi, A. O. 2007. Evaluation of fermented palm kernel meal and fermented copra meal proteins as substitute for soybean meal protein in laying hens diets. J. Central Europ. Agric., 9: 35-44.

Das, B., Arora, S. K. and Luthra, Y. P. 1977. A rapid method for determination of gum in guar [Cyamopsis tetragonoloba (L.) Taub], Proceedings of First ICAR Guar research workshop, Jodhpur, p. 117-123.

Davies, N. and Reid, H. 1979. An evaluation of the phytate, zinc, copper, iron and manganese contents of and $\mathrm{Zn}$ availability from, soya-based textured-vegetableprotein meat-substitutes or meat-extenders. Br. J. Nutr., 41: $579-589$

Dayal, J. S., Rajaram, V., Ambasankar, K. and Ahamad Ali, S. 2011. Sunflower oil cake as a replacement for fishmeal in feeds of Tiger Shrimp, Penaeus monodon reared in tanks and in net cages. Indian J. Geo-Marine Sci., 40: 460-470.

Emambux, M. N. and Taylor, J. N. 2003. Sorghum kafirin interaction with various phenolic compounds. J. Sci. Food Agric., 83: 402-407.

Finlayson, A. J. 1964. Amino acid recovering in the analysis of some feed samples. Can. J. Plant Sci., 45: 184-188.

Halweil, B. 2008. Farming fish for the future. Worldwatch Institute, Washington, DC, USA.

Hong, K. J., Lee, C. H. and Kim, S. W. 2004. Aspergillus oryzae GB-107 fermentation improves nutritional quality of food soybeans and feed soybean meals. J. Med. Food, 7: 430-436.

Imelda Joseph, Raj, P. and Bhatnagar, D. 2008. Effect of solid state fermentation on nutrient composition of selected feed ingredients. Indian J. Fish., 55: 327-332.

Kakade, M. L., Rackis, J. J., McGhee, J. E. and Puski, G. 1974. Determination of trypsin inhibitor activity of soy products: A collaborative analysis of an improved procedure. Cereal Chem., 51: 376-382.

Lipman, C. B. 1911. Nitrogen fixation by yeast and other fungi. http://www.jbc.org/content/10/3/169.full.pdf. (Accessed 28 April 2016)

Makkar, H. P. S. and Becker, K. 1997. Degradation of quillaja saponins by mixed culture of rumen microbes. Lett. Appl. Microbiol., 25: 243-245.

McGhee, J. E., Kirk, L. D. and Mustakas, G. C. 1965. Methods for determining thioglucosides in Crambe abyssinica. J. Amer. Oil Chem. So., 42: 889-891.

Mubarak, A. E. 2005. Nutritional composition and anti-nutritional factors of mung bean seeds (Phaseolus aureus) as affected by some home traditional processes. Food Chem., 89: 489-495.

Osman, M. A. 2011. Effect of traditional fermentation process on the nutrient and antinutrient contents of pearl millet during preparation of lohoh. J. Saudi Soc. Agric. Sci., 10: 1-6. 
Ravindra, A. P. 2000. Value-added food: single cell protein. Biotechnol. Advances, 18: 459-479.

Reddy, N. R. and Pierson, M. D. 1994. Reduction in anti-nutritional toxic components in plant by fermentation. Food Res. Int., 27: 281-290.

Roychaudhuri, R., Sarath, G., Zeece, M. and Markwell, J. 2004. Stability of the allergenic soybean Kunitz trypsin inhibitor. Biochim. Biophys. Acta, 1699: 207-212.

Sastry, C. S. P. and Tammuru, M. K. 1985. Spectrophotometric determination of tryptophan in protein. J. Food Sci. Technol., 22: 146-147.

Schober, R. 1930. Atmospheric nitrogen assimilation and acid formation in Aspergillus niger. Jahrb. Wiss. Bot., 72: 1-105.

Shankman, S. 1943. Amino acid nutrition of Lactobacillus arabinosus. http://www.jbc.org/content/150/2/305.full.pdf. (Accessed 16 April 2016)

Sharawy, Z., Goda, A. M. A. S. and Hassaan, M. S. 2016. Partial or total replacement of fishmeal by solid state fermented soybean meal with Saccharomyces cerevisiae in diets for
Indian white shrimp, Fenneropenaeus indicus, post-larvae. Anim. Feed Sci. Technol., 212: 90-99.

Sharma, M. K. and Kumawat, D. M. 2011. Co-inoculation study of Bradyrhizobium japonicum and Aspergillus niger in soybean for nitrogen fixation. J. Microbiol. Biotechnol. Food Sci., 1: 383-394.

Shi, C., He, J., Yu, J., Yu, B., Huang, Z., Mao, X., Zheng, P. and Chen, P. 2015. Solid state fermentation of rapeseed cake with Aspergillus niger for degrading glucosinolates and upgrading nutritional value. J. Anim. Sci. Biotechnol., 6: 13-19.

Tacon, A. G. J. and Metian, M. 2008. Global overview on the use of fishmeal and fish oil in industrially compounded aqua feeds: trends and future prospects. Aquaculture, 285: 146-158.

Van Soest, P. J. 1963. Use of detergents in the analysis of fibrous feeds. II. A rapid method for the determination of fiber lignin. J. Asso. Off. Arg. Chem., 46: 829-835.

Watson, T. G. 1976. Amino-acid pool composition of Saccharomyces cerevisiae as a function of growth rate and amino acid nitrogen source. J. General Microbiol., 96: $263-268$ 